\title{
Structural analysis of the embryonic development in Brycon cephalus (Günther, 1869)
}

\author{
Juliana Sversut de Alexandre ${ }^{1}$, Alexandre Ninhaus-Silveira ${ }^{2}$, Rosicleire Veríssimo-Silveira ${ }^{2}$, \\ Hellen Buzollo ${ }^{2}$, José Augusto Senhorini ${ }^{3}$ and Milena Penteado Chaguri ${ }^{2}$ \\ São Paulo State University - FMVZ, Animal Production Department, Botucatu; São Paulo State University, FEIS, Biology \\ and Zootecny Departament, Ilha Solteira; and Centro de Pesquisa e Gestão de Recursos Pesqueiros Continentais, ICMBIO, \\ Pirassununga, SP, Brazil
}

Date submitted: 17.04.09. Date accepted: 09.07.09

\section{Summary}

The embryogenesis of Brycon cephalus was established in seven stages: zygote, cleavage, blastula, gastrula, segmentation, larval and hatching, in an incubation period of $11 \mathrm{~h}\left(26^{\circ} \mathrm{C}\right)$. The zygote phase was observed directly after fertilization and egg hydration. Cleavage began at $0.5 \mathrm{~h}$ of incubation and extended up to the morula phase $(1.5 \mathrm{~h} ;+100$ blastomeres). Cleavage was meroblastic and underwent the following division pattern: the first five divisions were vertical and perpendicular to each other, following the model $2 \times 2$, $4 \times 2,4 \times 4$ and $4 \times 8$. The sixth division was horizontal and occurred at $1.25 \mathrm{~h}$ after fertilization, giving rise to two cell layers $(4 \times 8 \times 2)$ with 64 blastomeres. At the blastula stage $(1.25-1.5 \mathrm{~h})$, an irregular space between the blastomeres, the blastocoele, could be detected and the periblast structure initiated. The gastrula (1.75-6.0 h) was characterized by the morphogenetic movements of epiboly, convergence and cell involution, and formation of the embryonic axis. The segmentation stage (7-9 h) comprised the development of somites, the notochord, optic, otic and Kupffer's vesicles, neural tube, primitive intestine and ended with the release of the tail. The larval stage (up to $10 \mathrm{~h}$ ) was characterized by the presence of 30 somites and growth and elongation of the larvae. At the hatching stage, the embryos presented more than 30 somites and exhibited swimming movements and a soft chorion. The blastomeres presented euchromatic nuclei, indicating a high mitotic activity and many yolk globules in the cytoplasm. The periblast was constituted of a layer with several nuclei and many vesicles, which grew during the epiboly movement.

Keywords: Characidae, Characiforme, Embryo, Embryogenesis, Matrinxã

\section{Introduction}

Information about the embryonic development of different fish species is relevant to studies that focus on management of fisheries resources as well as to research related to captive rearing, and provides a deeper knowledge about the life history of the analysed species. In addition, the embryological approach

\footnotetext{
${ }^{1}$ All correspondence to: Juliana Sversut de ALEXANDRE. São Paulo State University - FMVZ, Animal Production Departament, 18610 - 000, P.O Box: 560, Botucatu - SP, Brazil. Tel:/Fax: +55 18 37431285. e-mail: jusversut@hotmail.com

${ }^{2}$ São Paulo State University - FEIS, Biology and Zootecny Departament, 15385 - 000, P.O. Box: 31, Ilha Solteira - SP, Brazil.

${ }^{3}$ Centro de Pesquisa e Gestão de Recursos Pesqueiros Continentais - ICMBIO, Pirassununga-SP, Brazil.
}

can contribute to studies regarding evolutionary relationships, inheritance pattern, mechanisms of development and the role of environmental influences over structural features of the organisms (lagler, 1959).

According to Flores (2002), fish embryology is a complex phenomenon that, besides being useful for ontogenetic issues, can serve as a tool to evaluate environmental quality, the effects of toxic substances on the aquatic fauna and act as experimental models under a variety of approaches.

The fish Brycon cephalus (Characiforme; Characidae) is a rheophilic species originally from the Amazon basin. The reproductive season of this species takes place during the rainy season, when the individuals perform a reproductive migration with full spawning (Castagnolli, 1992; Pereira Filho, 1994). Among the several neotropical fish families, the family Characidae stands out by presenting the largest number of freshwater fish species (Nelson, 1984). 
Bryconinae inhabit clear and well oxygenated waters. Despite feeding mainly upon fruit and seeds, they also show an omnivore feeding behaviour (Goulding, 1980). The stocks of B. cephalus have been depleted due to predatory fishing and deforestation of marginal areas, thus decreasing the available food sources (fruit, flowers, insects, etc.) (Matrinxã, 2005).

Woynarovich \& Horváth (1983) referred to species of the genus Brycon as some of the most commonly raised freshwater fish of tropical and temperate areas that present a great potential for intensive fish culture.

After migrating to their reproduction sites, the oocytes of these fish undergo several alterations, characterized by the conversion of vitellogenic oocytes into mature ones, just prior to ovulation (Woynarovich \& Horváth, 1983; Castagnolli, 1992; Freire-Brasil, 2001). Such maturation stage is blocked in specimens kept in captivity and hormone-inducted reproduction is required (Woynarovich \& Horváth, 1983; Freire-Brasil, 2001), a widespread strategy in neotropical fish culture systems.

Although the techniques of induced reproduction and incubation are properly established for distinct fish species, basic aspects of the embryonic stage in fish, from fertilization to hatching (Shardo, 1995) still remain poorly studied.

Little is known about the embryonic development of neotropical fish species, except for a few studies such as those carried out by Cardoso et al. (1995), Ribeiro et al. (1995), Andrade-Talmelli et al. (2001), Luz et al. (2001), Ganeco (2003) and Ninhaus-Silveira et al. (2006b).

According to Silveira (2000), the structural analysis of embryonic development gives useful information to studies focused on developing procedures for freezing and unfreezing fish embryos.

Fertilization promotes the activation of the female gametes, restarting meiosis, formerly stuck at metaphase II and triggering a chain of events in the interior of the oocytes (Freire-Brasil, 2002). According to Ohta (1991), fertilization is a process of cell fusion.

The spermatozoon penetrates the oocyte through the micropyle, a minute opening on the ovule surface (Ganeco, 2003) consisting of a funnel-like depression (Riehl, 1993). In addition, both the surface features on oocytes and the morphology of the micropyle apparatus represent important criteria for the identification of distinct teleostean species (Riehl, 1980) and analyses using scanning electron microscopy allow the observation of three-dimensional images, thus providing an accurate identification of the surface structures (Ganeco, 2003). Most bony fish species studied so far present a single micropyle on the chorion animal pole. However, the eggs of Polyodon spathula (Linhart \& Kudo, 1997) present several micropyles in the animal pole.

The micropyle plays a fundamental role, once fish spermatozoa lack acrosomes. Therefore, the spermatozoon interacts with the oocyte plasma membrane when crossing the micropyle (Iwamatsu, 2000). Embryonic development, focus of the present work, begins when both germ cells are joined together.

As a response to the cascade of events triggered by the fertilization process, the eggs undergo several alterations, such as cleavages, cell movement and the formation of rudimentary organs (Ganeco, 2003).

The cleavage in fish eggs follows a meroblastic or partial pattern, as it comprises just the animal pole (Balinsky, 1970 cited in Ganeco, 2003). Knowledge about reproductive biology and ontogenetic development is essential to the improvement of breeding techniques in intensive fish culture systems. Scanning electron microscopy (SEM) allows a detailed observation of the external structures in tissues and organs, providing a deeper analysis perspective and thereby adding new information to the data obtained by light microscopy studies.

As the eggs of distinct fish species may differ in size, shape, colour, number and specific density, the description of the embryonic stages can be helpful in the identification of viable eggs in studies focusing on productivity and survival (Lagler, 1959).

Therefore, the structural analysis of the events related to induced reproduction, fertilization and embryonic development within a given period of time potentially contributes to a better understanding of the reproduction features in teleosteans and their proper management in fish cultures (Ganeco, 2003).

Thus, this experiment was carried out in order to provide a morphological analysis of the first steps of fertilization and embryonic development in B. cephalus throughout embryogenesis by using both light and scanning electron microscopy.

\section{Materials and methods}

\section{Sample collection}

Both reproduction and collection of B. cephalus embryos were performed between 13 and 17 November 2006 at CEPTA - Centro de Pesquisa e Gestão de Recursos Pesqueiros Continentais - ICMBIO (Instituto Chico Mendes de Conservação da Biodiversidade). In this experiment three females (1200 kg each) and three males (1 kg each) were used. Hormone-induced spawning was performed according to Woynarovich \& Hórvath (1980) by using carp (Cyprinus carpio) pituitary extract. The females were inoculated twice with $0.5 \mathrm{mg}$ and $5.0 \mathrm{mg} / \mathrm{kg}$ body weight, respectively, at $8.5 \mathrm{~h}$ intervals at a mean temperature of $26^{\circ} \mathrm{C}$. The males were inoculated simultaneously to the second application in females, using a concentration of $1 \mathrm{mg} / \mathrm{kg}$ body weight. The extrusion of oocytes and 
sperm was performed through abdominal massage after $7 \mathrm{~h}$ at $26^{\circ} \mathrm{C}$ (182 h-degree - accumulated h mean $\mathrm{T}^{\circ} \mathrm{C}$ ) since the last induction shot.

The fertilization process followed the dry method (Ninhaus-Silveira et al., 2006), in which the eggs are mixed with the sperm in a water-free environment. Water was then added to activate the spermatozoa and egg hydration. After $20 \mathrm{~min}$, the fertilized eggs were rinsed off to remove the excess semen and placed into 60-litre vertical incubators at a controlled temperature.

Collection of samples was performed from the moment of oocyte extrusion, through fertilization (time zero) and embryogenesis, every $15 \mathrm{~min}$ during the first $2 \mathrm{~h}$ and then at each hour up to hatching, in order to analyse the structural modifications in the oocytes during fertilization and the morphotemporal alterations in the embryos of $B$. cephalus.

Each sampling collection was divided into two samples. One of them was fixed in modified Karnovsky's solution (4\% paraformaldehyde and 2\% glutaraldehyde in $0.1 \mathrm{M}$ phosphate buffer, $\mathrm{pH}$ 7.3) and the other was fixed in $2.5 \%$ glutaraldehyde, rinsed in $0.1 \mathrm{M}$ sodium phosphate buffer $\mathrm{pH} 7.2$ after $24 \mathrm{~h}$ and stored in $70 \%$ alcohol.

\section{Light microscopy}

Analyses using light microscopy were performed with samples fixed with modified Karnovsky's fixative. Morphotemporal analysis of in toto embryonic development was carried out under a stereomicroscope. For this procedure, 50 embryos per sample were separated and stained with Harris haematoxylin-eosin (H\&E) and toluidine blue to determine the embryonic stages and the percentage of embryos at each stage.

The most representative embryos at each embryonic stage were selected for the micrographs and histological slides were then prepared. This procedure was carried out in the Laboratory of Neotropical Ichthyology at the Engineering College - UNESP, Ilha Solteira, São Paulo, Brazil, using a light microscope coupled with a Moticam 2000 digital camera (Motic Instruments Inc.) and in the laboratory of the Dental Department at the Dentistry College - UNESP, Araçatuba, São Paulo, Brazil, using an Axiophot-Zeiss DSM-940A light microscope.

For the histological analysis under a light microscope, representative samples of embryos from each stage were dehydrated in an alcohol series at increasing concentrations and embedded individually into glycol methacrylate for further microtomy to obtain serial transversal and longitudinal cuts ranging from 3 to $5 \mu \mathrm{m}$. The cuts were then stained with H\&E and toluidine blue, analysed and photographed under a Bioval L2000 microscope coupled with a digital camera (Motic Instruments Inc.).

\section{Scanning electron microscopy}

The samples that had been fixed in $2.5 \%$ glutaraldehyde were post-fixed in a solution of osmium tetroxide at $1 \%$ for $2 \mathrm{~h}$ and washed in $0.1 \mathrm{M}$ sodium phosphate buffer $\mathrm{pH}$ 7.2. Dehydration was accomplished by using an increasing alcohol series at 30, 50, 70, 80, 90 and $95 \%$ plus two baths at $100 \%$ ethanol (15 min at each step). The material was critical point dried in a liquid $\mathrm{CO}_{2}$ drier (BALTEC), mounted onto stubs and coated in gold-palladium ions using a Balzers metallizer MED010 . The prepared samples were examined and electron micrographed in a ZEISS DSM 940A scanning electron microscope (NAP/MEPA-ESALQ/USP).

\section{Results}

\section{Fertilization}

Brycon cephalus presents external fertilization, producing pelagic, non-adhesive, spherical, translucent and greenish oocytes, characterized by a large perivitelline space after hydration that persisted up to embryo formation. In relation to the quantity and distribution pattern of yolk, the eggs of B. cephalus can be classified as polylecithal, once they display a large amount of yolk and telolecithal, as the yolk is concentrated in the vegetative pole while the cytoplasm and organelles are distributed over the animal pole.

The embryonic development of B. cephalus, from the fertilization up to larval hatching, lasted $11 \mathrm{~h}$ at $26^{\circ} \mathrm{C}$. The oocyte surface, corresponding to the chorion or zona radiata, presented several pores and a single micropyle. The micropyle was characterized by a small funnel-like opening on the animal cell pole, through which the spermatozoon penetrates the oocyte (Fig. 1). This structure allows the entry of a single spermatozoon in the final micropyle portion, thus helping in preventing the polyspermy (Fig. 1).

Within the samples collected at the fertilization moment, several spermatozoa could be detected along the entrance and the vestibulum of the micropyle (Fig. $1 E, F)$.

\section{Embryogenesis}

The following stages were established for the embryonic development of $B$. cephalus: zygote, cleavage, blastula, gastrula, segmentation, larval and hatching (Table 1).

\section{Zygote stage}

The moment in which the oocytes and the sperm were mixed was referred to as time zero. In this stage, the eggs became hydrated, leading to a significant increase in the perivitelline space, coupled with cytoplasm 


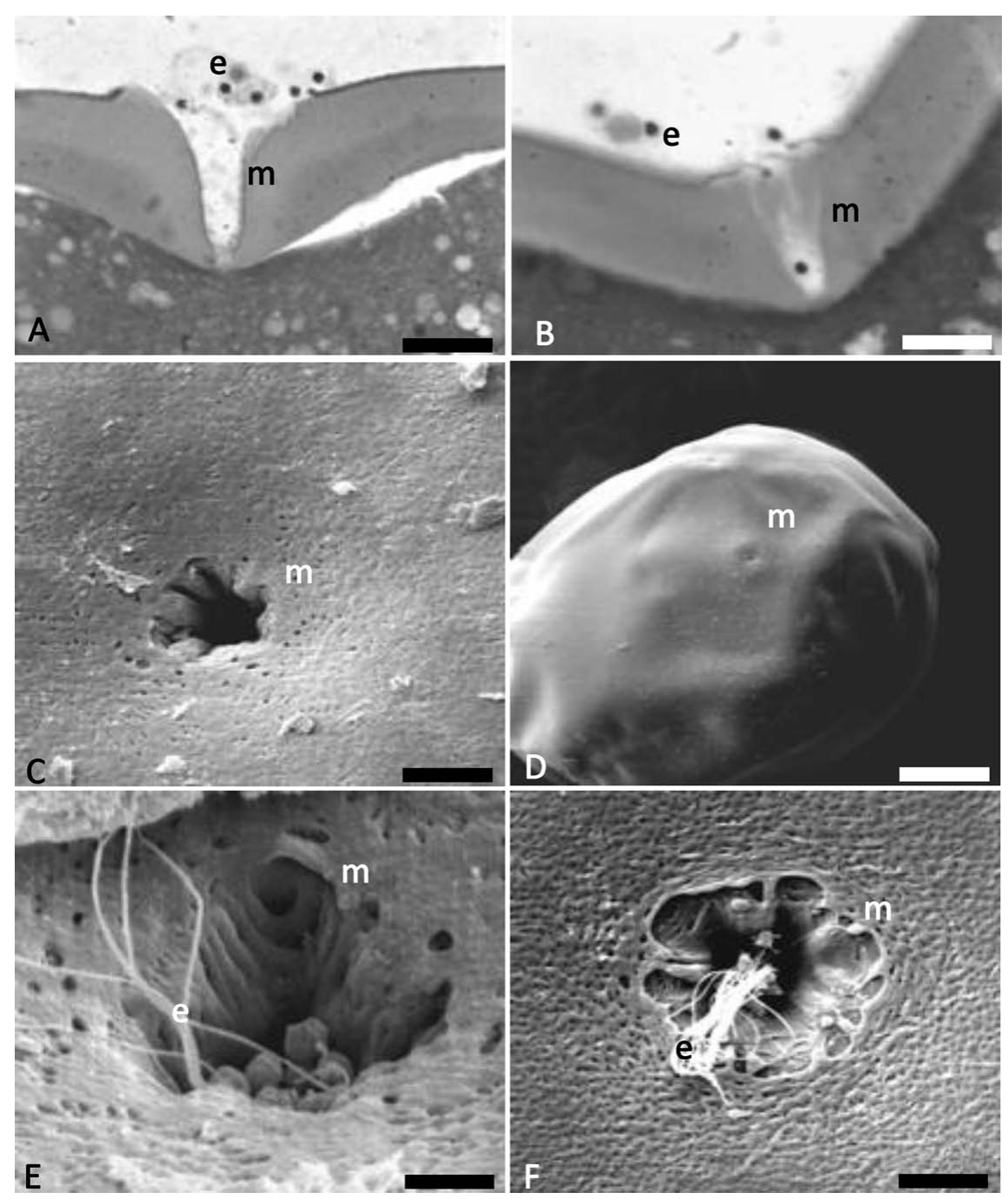

Figure 1 Micropyle. $(A, B)$ cut of the micropyle with spermatozoa after toluidine blue staining. $(C, D)$ micropyle at SEM. ( $E$, $F)$ several spermatozoa along the entrance and the vestibulum of the micropyle. e, spermatozoon; m, micropyle. Scale bars: $A$, $10 \mu \mathrm{m} ; B, 9.5 \mu \mathrm{m} ; C, 4.1 \mu \mathrm{m} ; D, 42.5 \mu \mathrm{m}$.

migration and organization of both animal pole, comprising the active cytoplasm and the nucleus, and vegetative pole, composed of the yolk sac.

At stereomicroscopy, the animal pole was more translucent and darker than the vegetative pole, which presented a clearer and opaque colouration, being composed of yolk globular vesicles (Fig. $2 A, B, D, F$ ). Under the light microscope, a thin cytoplasm layer comprising several cortical alveoli could be detected surrounding the whole yolk sac. Embryos at the zygote stage were observed up to $45 \mathrm{~min}$ of embryogenesis (Fig. 3).

\section{Cleavage stage}

This stage began $30 \mathrm{~min}$ after the start of embryonic development and lasted until $1 \mathrm{~h}$ and $30 \mathrm{~min}$ of embryogenesis (Table 1). In B. cephalus, cleavage is meroblastic or partial as it takes place only at the animal pole (Fig. 4).

The cleavage stage was characterized by the first mitotic divisions and it continued up to the formation of irregular spaces among intern cells, which might be considered a kind of blastocoele. The cleavage pattern could be reported as follows: the first cleavage plane was vertical, giving rise to two blastomeres; the second plane was vertical and perpendicular to the first one, giving rise to four blastomeres; the third cleavage was vertical and parallel to the first one, giving rise to eight blastomeres in a $4 \times 2$ arrangement; the fourth was vertical and parallel to the second cleavage, giving 16 blastomeres in a $4 \times 4$ display; the fifth plane was vertical and parallel to the first cleavage, giving 32 blastomeres in a $4 \times 8$ formation; and the sixth cleavage plane was horizontal, giving rise to two cell layers, with a total of 64 blastomeres (Figs. 4; $5 A-G$ ). 
Table 1 Embryonic development of 'matrinxã', Brycon cephalus, at $26.8^{\circ} \mathrm{C}$.

\begin{tabular}{|c|c|c|}
\hline Time (h) & Stage & Description \\
\hline $0-0.25$ & Zygote & Cytoplasm streams towards the animal pole to form the blastodisc \\
\hline 0.5 & Zygote/Cleavage & $66 \%$ without cleavage; $34 \%$ with 2 cells \\
\hline 0.75 & Zygote/Cleavage & $14 \%$ without segmentation; $26 \%$ with 2 cells; $50 \%$ with 4 cells; $10 \%$ with 8 cells \\
\hline 1.0 & Cleavage & $84 \%$ with 16 cells; $16 \%$ with 8 cells \\
\hline 1.25 & Cleavage/Blastula & $4 \%$ without cleavage; $26 \%$ with 32 cells; $56 \%$ with 64 cells; $14 \%$ morula \\
\hline 1.5 & Cleavage/Blastula & $22 \%$ with 64 cells; $78 \%$ morula \\
\hline 1.75 & Blastula/Gastrula & $14 \%$ morula; $60 \%$ gastrula ( $25 \%$ epiboly); $25 \%$ gastrula ( $50 \%$ epiboly) \\
\hline 2.0 & Gastrula & $28 \%$ gastrula ( $25 \%$ epiboly); $66 \%$ gastrula ( $50 \%$ epiboly); $6 \%$ gastrula ( $75 \%$ epiboly) \\
\hline 3.0 & Gastrula & $88 \%$ gastrula ( $25 \%$ epiboly); $12 \%$ gastrula ( $50 \%$ epiboly) \\
\hline 4.0 & Gastrula & $10 \%$ gastrula ( $50 \%$ epiboly); $90 \%$ gastrula ( $75 \%$ epiboly) \\
\hline 5.0 & Gastrula & $100 \%$ gastrula ( $75 \%$ epiboly) \\
\hline 6.0 & Gastrula & $100 \%$ gastrula ( $90 \%$ epiboly) \\
\hline 7.0 & Segmentation & $\begin{array}{l}8 \% \text { with } 11 \text { somites; } 90 \% \text { with } 13 \text { somites; } 2 \% \text { with } 9 \text { somites; optic vesicle; Kupffer vesicle; } \\
\text { tail attached }\end{array}$ \\
\hline 8.0 & Segmentation & $\begin{array}{l}\text { 18\% with } 17 \text { somites; } 74 \% \text { with } 18 \text { somites; } 8 \% \text { with } 19 \text { somites; optic and otic vesicles; } \\
\text { Kupffer vesicle in regression; tail attached }\end{array}$ \\
\hline 9.0 & Larval & $100 \%$ with 26 somites; optic and otic vesicles; Kupffer vesicle is absent; free tail \\
\hline 10.0 & Larval & $100 \%$ with 30 somites; optic and otic vesicles; development of the intestine; embryo growth \\
\hline 11.0 & Hatching & $100 \%$ with $30+$ somites; intestine in development; hatching \\
\hline
\end{tabular}

For as long as the cleavage continues, the number of blastomeres increases and their size diminishes. Until the third cleavage the cells were homogeneous, but from the fourth cleavage plane onwards blastomeres of distinct sizes could be observed.

The yolk globules penetrated the blastomeres in a fragmented way, probably to facilitate their absorption by the cells.

\section{Blastula stage}

At this stage, the blastoderm presented a half-moon shape. The cleavage pattern was rather undetermined but continuous.

The spaces between the blastomeres (blastocoele) were irregular at this stage and the formation of the yolk syncytial layer or periblast was initiated (Figs. $2 A$, $B, D ; 5 H)$. The end of this stage was characterized by the first epiboly movements.

\section{Gastrula stage}

The gastrula stage started after $1 \mathrm{~h}$ and $45 \mathrm{~min}$ of embryonic development (Table 1), when the epiboly movements were predominant (Figs. 2G; 5I, J) along with the occurrence of the morphogenetic movements of convergence and cellular involution that ultimately will give rise to the first layers and to head-tail and latero-lateral embryonic axes.

The yolk syncytial layer was formed across the blastoderm border, from its formation to the closure of the blastopore (Figs. 2G; 5I, J). The morphogenetic movements of convergence and cell migration started at the blastoderm border, at about $50 \%$ of epiboly (Fig. 2G), giving the germination ring, the embryonic shield and culminating with the formation of two embryonic layers: the epiblast and hypoblast.

The epiboly movement proceeded together with the covering of the yolk sac by the periblast and it ended after $6 \mathrm{~h}$ of development with the complete closure of the yolk plug by the blastoderm (Fig. 5I, J).

\section{Segmentation}

This stage was characterized by the formation of rudimentary organs and systems from the embryonic layers. Segmentation was initiated after $7 \mathrm{~h}$ of development and it lasted up to $9 \mathrm{~h}$ of embryogenesis (Table 1). The somites, the notochord and the neural tube were developed at this stage, as well as the early delimitation of the intestine and elongation of the embryo, mainly at the head-tail axis. The release of the tail pointed to the end of segmentation.

After $7 \mathrm{~h}$ of development the embryos presented about 13 somites, optic, otic and Kupffer's vesicles (Fig. 2E) at the caudal region and the tail was attached; after $8 \mathrm{~h}$, the embryos presented about 18 somites, plus optic and otic vesicles. By the end of this stage, the Kupffer's vesicle retreats and the embryo tail becomes free (Fig. 6).

At this phase, the neural tube begins to be formed and, as long as its sections undergo differential growth, the prosencephalon, mesencephalon and rhombencephalon regions can be identified (Fig. 6C, D). 

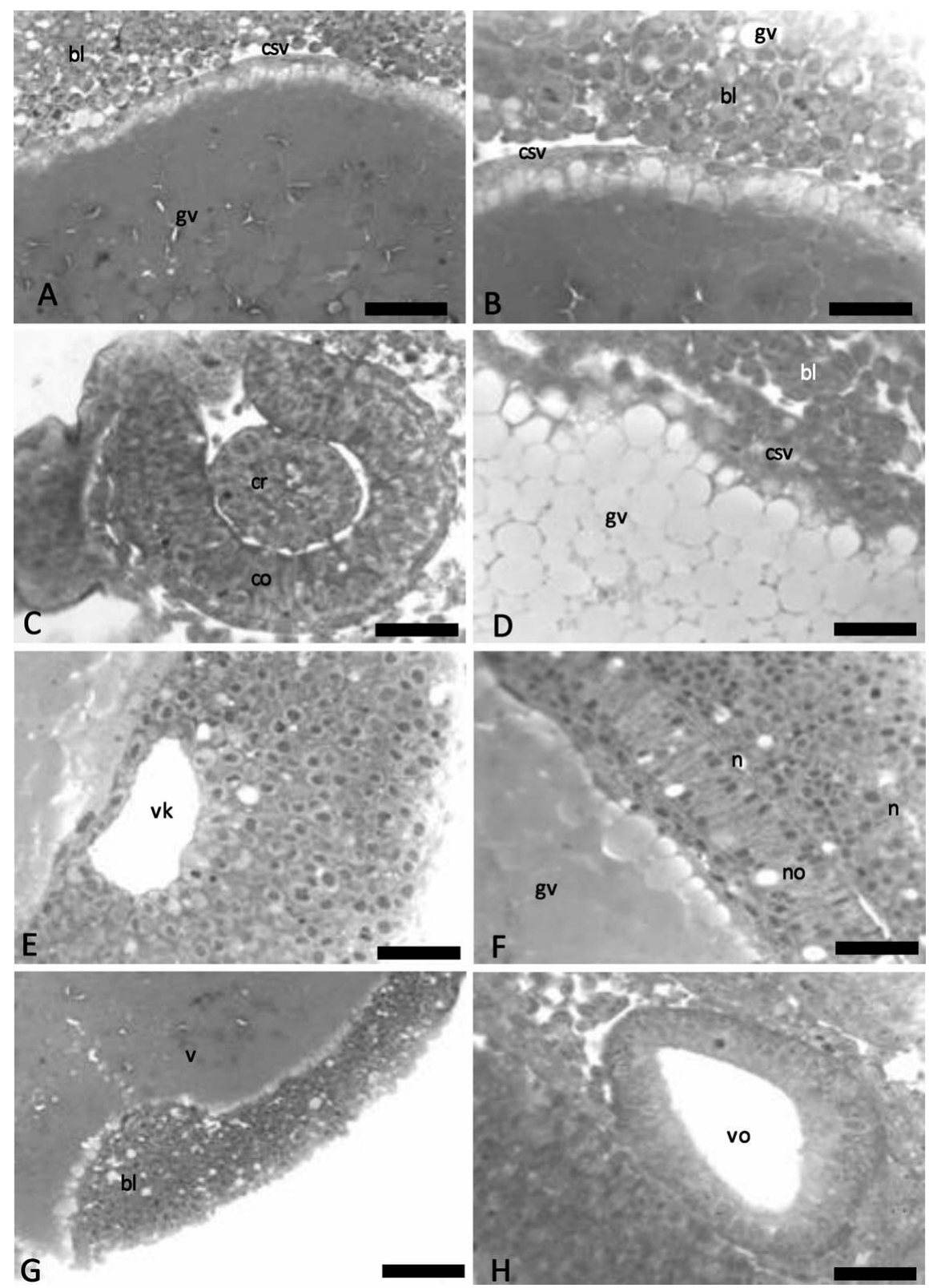

Figure 2 Histological cuts after HE and toluidine blue staining. $(A, B)$ embryo cut at $50 \%$ of epiboly; $(C)$ cut showing the optic vesicle; $(D)$ cut showing the yolk globules and the blastoderm; $(E)$ cut of the Kupffer's vesicle; $(F)$ Notochord; $(G)$ embryo at $50 \%$ of epiboly; $(H)$ otic vesicle. bl, blastoderm; co, optic calyx; cr, crystalline; csv, yolk syncytial layer; gv, yolk globules; n, nucleus; no, notochord; v, yolk; vk, Kupffer's vesicle; vo, otic vesicle. Scale bars: $A, 11.5 \mu \mathrm{m} ; B, 17.5 \mu \mathrm{m} ; C, 16.7 \mu \mathrm{m} ; D, 3.6 \mu \mathrm{m}$; $E, 80 \mu \mathrm{m} ; F, 5.7 \mu \mathrm{m}$.

\section{Larval stage}

The larval stage ranged from 9 to $10 \mathrm{~h}$ after the development (Fig. 7), being characterized by the presence of a free tail and more that 26 somites (Table 1). The optic calyx, crystalline lens and the optic vesicle were well developed at this stage (Fig. 2C). The notochord extended from the cephalic region up to the tail (Fig. 7) and a well defined primitive posterior intestine was observed (Fig. 7).

Spasmodic embryo movements were also detected at this stage and they intensified throughout the embryonic development.

\section{Hatching}

Hatching occurred after $11 \mathrm{~h}$ of development (Table 1). At this stage, the larvae already performed strong swimming movements, essential to break the chorion.

\section{Discussion}

Features found in the eggs of B. cephalus are similar to those described for species of the genus 


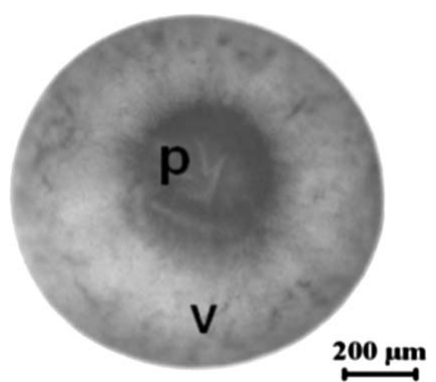

Figure 3 Embryo at the zygote stage. p, animal pole; v, vegetative pole. Scale bar: $200 \mu \mathrm{m}$.

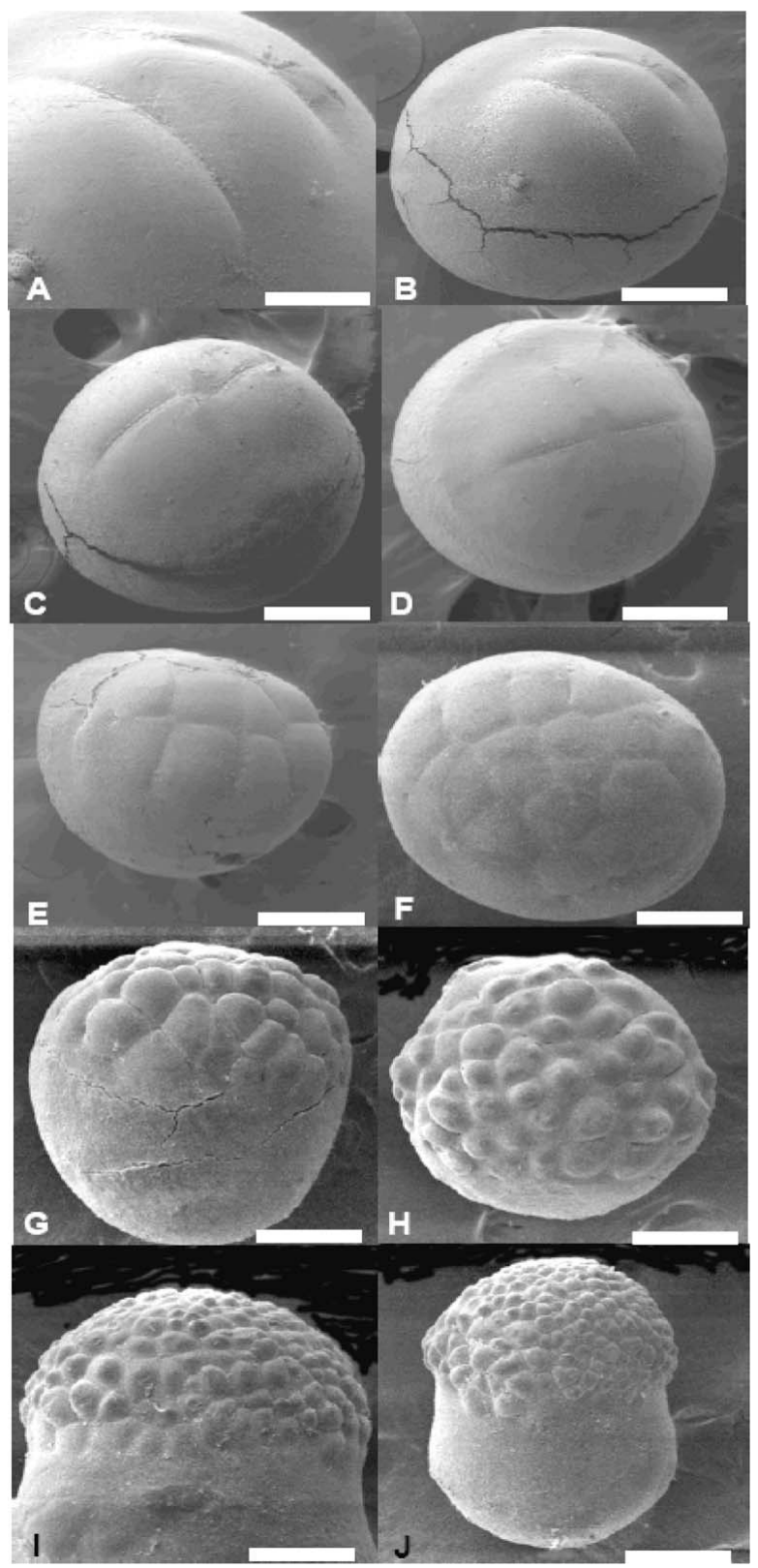

Figure 4 Cleavages under scanning electron microscope. $(A$, $B)$ 2-cell embryo; $(C, D)$ 4-cell embryo; $(E)$ 8-cell embryo; $(F)$ 16-cell embryo; $(G)$ 32-cell embryo; $(H)$ 64-cell embryo; ( $I$, $J)$ embryo at morula. Scale bars: $A, 130 \mu \mathrm{m} ; B-I, 263 \mu \mathrm{m} ; J$, $200 \mu \mathrm{m}$.
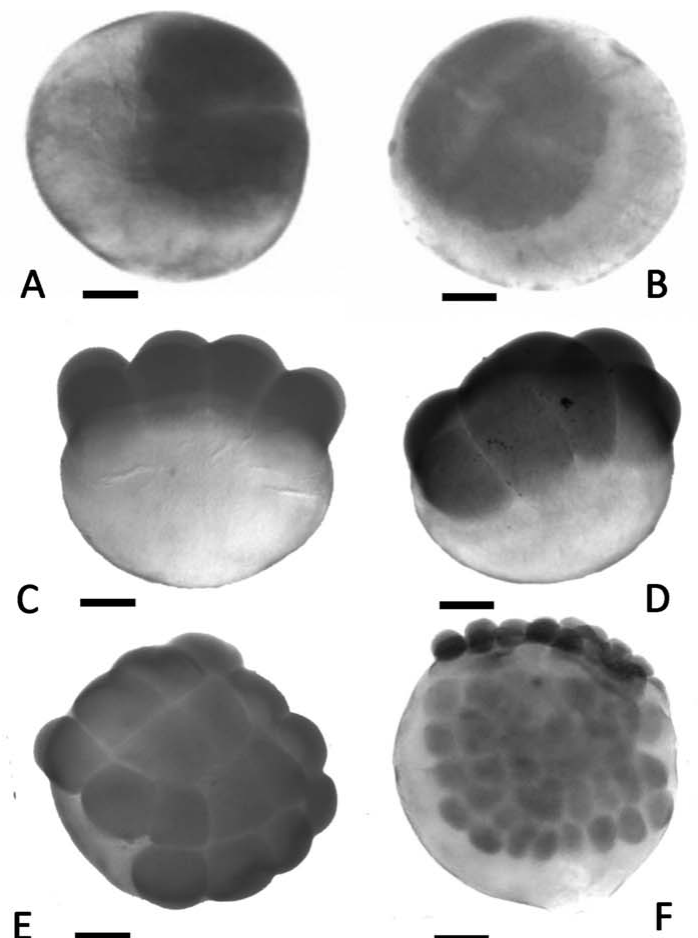

E

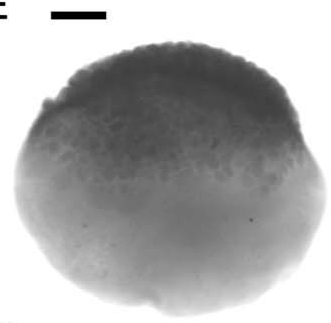

G
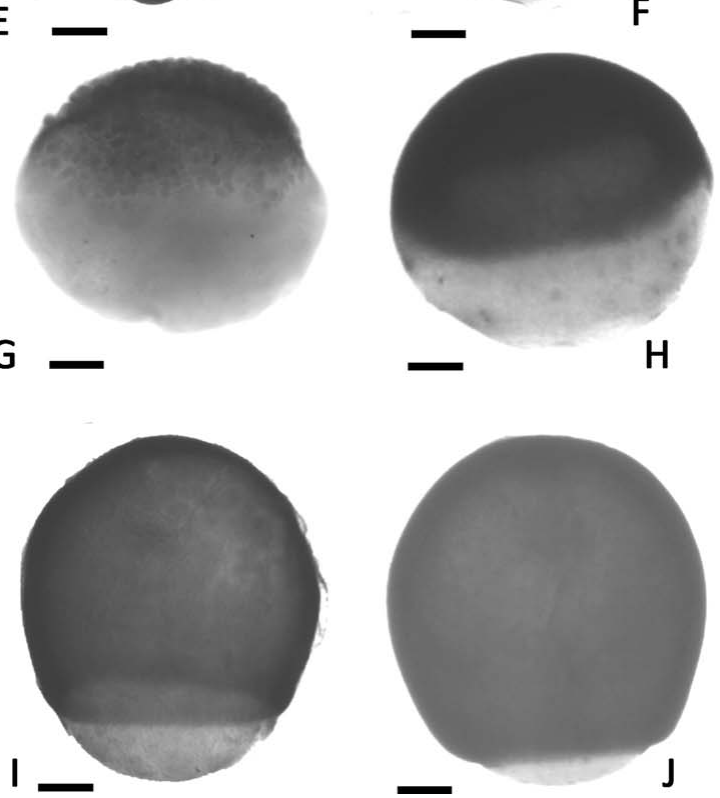

Figure 5 Development stages in Brycon cephalus. (A) 2-cell embryo; $(B)$ 4-cell embryo; $(C, D)$ 8-cell embryo; $(E)$ 16-cell embryo; $(F)$ 32-cell embryo; $(G)$ 64-cell embryo; $(H)$ morula; (I) $75 \%$ of epiboly; $(J) 90 \%$ of epiboly. Scale bars: $200 \mu \mathrm{m}$.

Brycon (Eckmann, 1984; Andrade-Talmelli et al., 2001; Romagosa et al., 2001; Ganeco, 2003).

Ganeco (2003) reported a single micropyle in eggs of Brycon orbignyanus, presented as a depression in the zona radiata, similarly to that identified for B. cephalus in this study. According to Riehl (1993) and Laale (1980), the micropyle represents a small opening located in the animal pole that helps the spermatozoon penetrate the oocyte. In studies performed by Kobayashi \& 


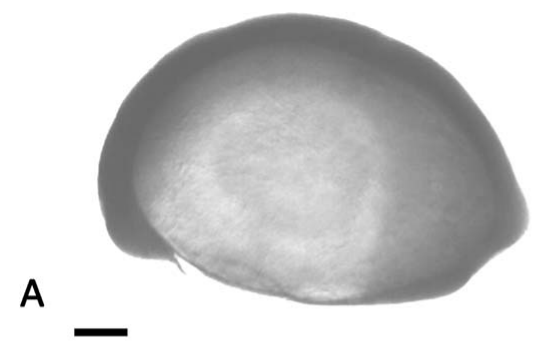

B
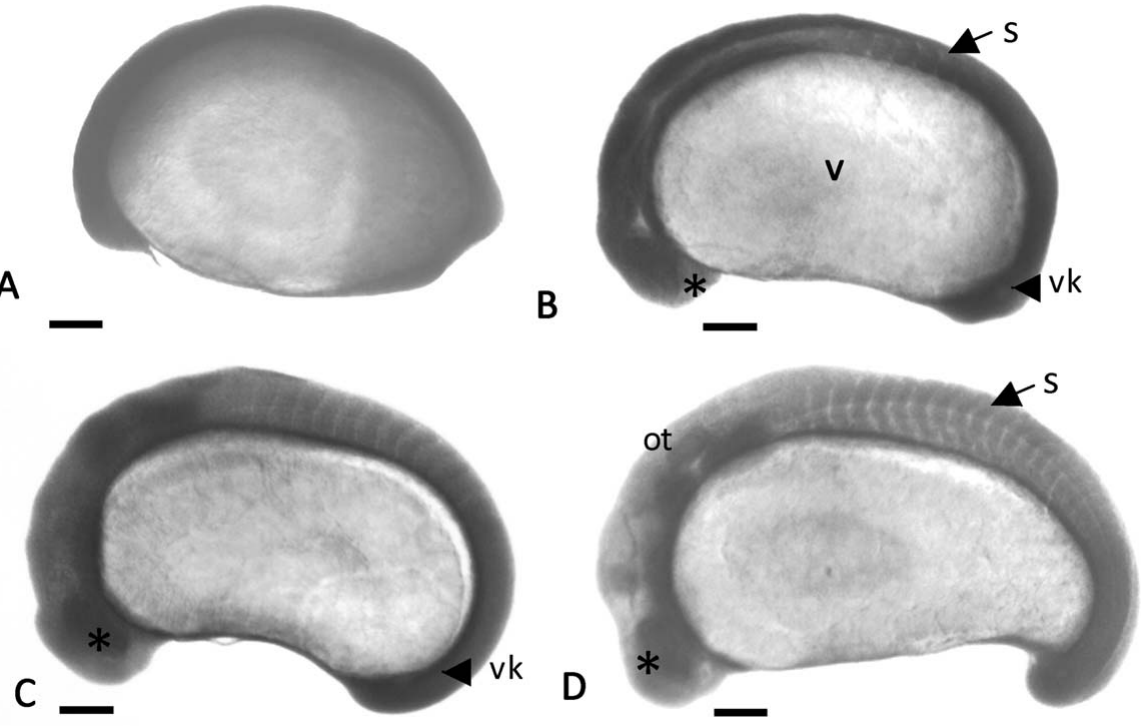

Figure $6(A)$ Neurula; $(B)$ Initial appearance of somites, optic and Kupffer's vesicles, attached tail; $(C)$ embryo with about 13 somites, optic and Kupffer's vesicles, attached tail; $(D)$ more than 20 somites, presence of optical and otic vesicles, retreated Kupffer's vesicle and a nearly free tail. ot, otic vesicle; s, somite; vk, Kupffer's vesicle; * - optic vesicle. Scale bars: $A$, $55 \mu$ m; $B$, $57.1 \mu \mathrm{m} ; \mathrm{C}, 70.4 \mu \mathrm{m} ; D, 76.3 \mu \mathrm{m}$.

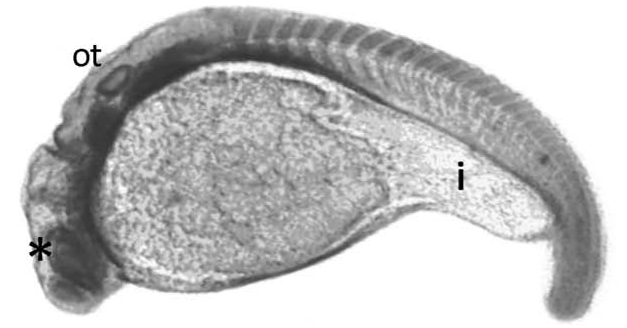

A

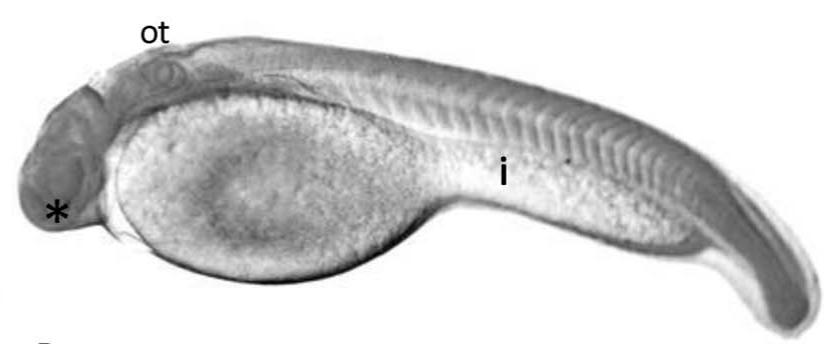

B

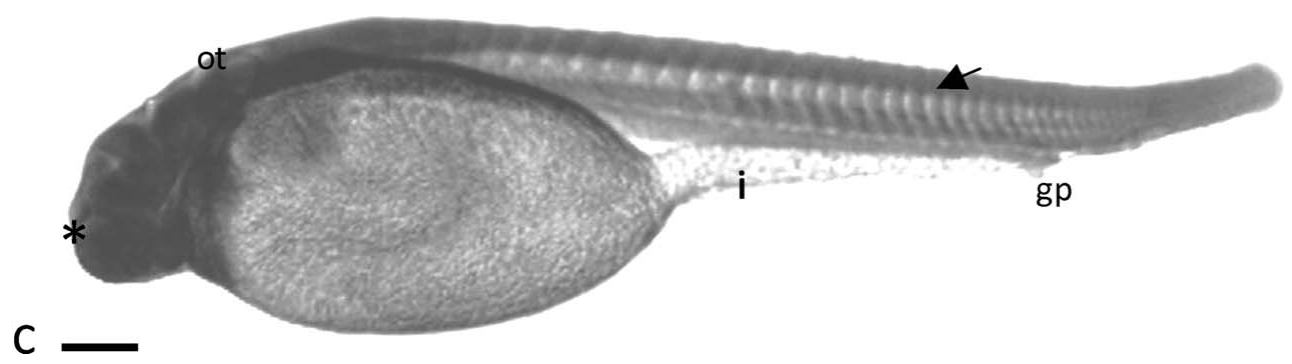

Figure 7 Larval. $(A)$ more than 26 somites; growing larva; $(B)$ pre-hatching embryo; $(C)$ hatched larva. gp, genital pore; i, primitive posterior intestine; ot, otic vesicle; *, optic vesicle. Scale bars: $A, 63.3 \mu \mathrm{m} ; B, 75.6 \mu \mathrm{m} ; C, 69.4 \mu \mathrm{m}$.

Yamamoto (1981) and Rizzo \& Bazzoli (1993), a funnellike shape in micropyle was revealed, in which the internal canal opening allows the entrance of a single spermatozoon, following the same pattern observed in the present work.

The pores in the zona radiata of B. cephalus eggs have also been reported in several Characiformes, occupying regular spaces over the vegetative pole and reaching a higher diameter and a larger number towards the micropyle (Rizzo et al., 2002). Such increase in the number and size of pores at the micropylar region might provide better aeration to the embryo (Braum, 1978, cited in Rizzo, 2001).

Just like the report by Nakagui (2005) on Salminus brasiliensis, the 'matrinxã' eggs presented a large perivitelline space, which protects the embryos from environmental hazards and increases the survival in fast-flowing waters. 
According to Balinsky (1970), cited in Ganeco (2003), because of their great amount of yolk, fish eggs display a meroblastic (incomplete) segmentation, similarly to the pattern observed in teleosteans of the genus Brycon.

A first cleavage plane that originates two blastomeres of identical size has formerly been identified in other fish species, such as Oryzias latipes (Iwamatsu, 1994) and Prochilodus scrofa (Ninhaus-Silveira et al. 2006). According to Shardo (1995) in Alosa sapidissima, the cleavage starts from the centre to the borders of the blastodisc, followed by successive cleavages up to a 64-blastomere stage. Furthermore, the blastomeres became smaller as long as their number increased, a feature also observed in B. orbignyanus (Ganeco, 2003), Prochilodus lineatus (Ninhaus-Silveira et al., 2006) and in B. cephalus studied at present.

The embryonic development of B. cephalus was divided into seven stages: zygote, cleavage, blastula, gastrula, segmentation, larval and hatching, as well as observed in Prochilodus lineatus (Ninhaus-Silveira, 2006).

According to Ganeco (2003), the pattern of the first cleavage planes is characteristic of the studied species. Like most of teleosteans (Shardo, 1995), the embryos of B. cephalus presented four 4-cell lines at the 16-cell stage, composing of a single cell layer; four 8-cell lines were formed when the 32-cell phase was reached, although some blastomeres displayed distinct sizes.

Fat drops were not observed inside the yolk of $B$. cephalus eggs, a situation commonly found in other Characiformes, such as Brycon orbignyanus (Ganeco, 2003), Prochilodus lineatus (Ninhaus-Silveira, 2004) and Brycon insignis (Andrade-Talmelli et al., 2001). However, Lopes et al. (1995), analysing eggs of 'matrinxã', reported the presence of a single fat drop during the embryonic development of this species.

The yolk syncytial layer in B. cephalus was observed at the blastula stage. This feature was also observed in Prochilodus lineatus (Ganeco, 2003; Ninhaus-Silveira, 2006).

Kimmel et al. (1995) stated that the yolk syncytial layer is a unique organ of teleosteans, composed of an extra-embryonic structure, thus not related to the formation of the embryo body. This cell layer, also named periblast, differentiates from the other cells in the blastoderm by presenting a higher basophilic affinity (Balinsky, 1970 cited in Ganeco, 2003).

According to Shardo (1995), the embryonic period encompasses the fertilization up to the hatching, including cleavage, gastrulation, neurulation and the beginning of organogenesis. Epiboly movements in eggs of $B$. cephalus were firstly detected by the end of gastrula up to the beginning of the gastrula stage. These movements were followed by the emergence of a germination ring on the marginal blastoderm border and subsequent formation of the embryonic shield.
Similar evidence was detected in Brycon orbignyanus (Ganeco, 2003) and Alosa sapidissima (Shardo, 1995).

The embryonic shield in B. cephalus becomes visible when the blastoderm covered $50 \%$ of the yolk sac, following the pattern formerly reported for other fish species (Hisaoka \& Firlit, 1960; Kimmel, 1995; Ganeco, 2003; Ninhaus-Silveira et al., 2006).

According to Hisaoka \& Firlit (1960), the Kupffer's vesicle represents a remnant structure of the archenteron that is located over the periblast and below the notochord. In Oncorhynchus keta (Mahon \& Hoar, 1956 cited in Hisaoka \& Firlit, 1960), the Kupffer's vesicle is described as an oblique and elongated cavity with columnar epithelial walls that is separated from the periblast by a layer of endoderm cells. The histology of this structure in $B$. cephalus was similar to that reported in O. keta.

Following the proposition by Kimmel (1995), the neurula stage was included into the segmentation stage. Brummett \& Dumont (1978) and Morrison (2001) observed the Kupffer's vesicle in the segmentation phase. In the present work, it was detected when the embryo reached a 13-somite phase. From the 24-somite state on, this vesicle disappeared and its function remains unknown. Nonetheless, Brummet \& Dumont (1978) hypothesized that such structure could play a role in the digestion process, assisting the yolk absorption by the embryo, once ciliated cells were identified in both the Kupffer's vesicle and the intestine of Fundulus heteroclitus.

According to Silveira (2001), the ectoderm on the notochord is transformed into a neural plate, which becomes centrally depressed giving rise to the neural keel that following a posterior enclosure by the fusion of the neural filaments, originates the neural tube. As observed in B. cephalus, the prosencephalon, mesencephalon and rhombencephalon regions were developed from the posterior portion of the neural tube, corroborating the description about the embryonic development reported for Brycon orbignyanus (Ganeco, 2003) and Prochilodus lineatus (Ninhaus-Silveira et al., 2006).

\section{Acknowledgements}

This work was supported by the Centro de Pesquisa e Gestão de Recursos Pesqueiros Continentais ICMBIO/Pirassununga/São Paulo/Brazil, which provided the fish and the facilities used in this study and also by FAPESP (Fundação de Amparo a Pesquisa do Estado de São Paulo).

\section{References}

Andrade-Talmelli, E.F., Kavamoto, E.T., Romagosa, E. \& Fenerich-Verani, N. (2001). Embryonic and a larval 
development of the 'Piabanha,' Brycon insignis, Steindachner, 1876 (PISCES, CHARACIDAE). Boletim do Instituto de Pesca 27(1), 21-28.

Brummett, A.R. \& Dumont, J.N. (1978). Kupffer's vesicle in Fundulus heteroclitus: a scanning and transmission electron microscope study. Tissue Cell 10, 11-22.

Cardoso, E. L., Alves, M.S.D., Ferreira, R.M.A. \& Godinho, H. P. (1995). Embryogenesis of the neotropical freshwater siluriforme Pseudoplatystoma coruscans. Aquat Living Res. 8, 343-346.

Castagnolli, N. (1992). Criação de peixes de água doce. Jaboticabal: FUNEP.

Eckmann, R. (1984). Induced reproduction in Brycon cf. erythropterus. Aquaculture 38, 370-382.

Flores, J.C.B., Araiza, M.A.F. \& Valle, M.R.G. (2002). Desarrollo embrionario de Ctenopharyngodon edellus (Carpa herbívora). [online], CIVA2002. Available from: http:/ / www.civa2002.org, pp. 792-797.

Freire-Brasil, D. (2001). Análise estrutural e ultraestrutural da maturação final do ovócito, fertilização e primeira clivagem em curimbatá, Prochilodus lineatus Valenciennes, 1836. Doctor's degree. Universidade Estadual Paulista, Jaboticabal.

Freire-Brasil, D., Nakaghi, L.S.O., Santos, H.S.L., Grassiotto, I.Q. \& Foresti, F. (2001). Estudo morfológico dos primeiros momentos da fertilização em curimbatá Prochilodus lineatus (Valenciennes, 1836). [online], CIVA 2002. Available from: http:/ / www.civa2002.org, pp. 733-747.

Ganeco, L.N. (2003). Análise dos ovos de piracanjuba, Brycon orbignyanus (Valenciennes, 1849), durante a fertilização $e$ $o$ desenvolvimento embrionário, sob condições de reprodução induzida. Masters degree. Universidade de Estadual Paulista, Jaboticabal.

Goulding, M. (1980). The fishes of the forest: exploration in Amazonian Natural History. 280. Berkeley: University of California Press.

Hisaoka, K.K. \& Firlit, C.F. (1960) Further studies on the embryonic development of the zebrafish, Brachidanio rerio (Hamilton-Buchanan). J Morphol. 107, 205225.

Iwamatsu, T. (2000). Fertilization in fishes. In: Fertilization in Protozoa and Metazoa Animals. Heidelberg: Springer-Verlag Berlin. pp. 89-145.

Iwamatsu, T. (1994). Stages of normal development in the medaka Oryzias latipes. Zool. Sci. 11, 825-839.

Kimmel, C.B. \& Law, R.D. (1995). Cell lineage of zebrafish blastomeres. II. Formation of the yolk syncitial layer. Devel. Dynamics 203, 253-310.

Kobayashi, W. \& Yamamoto, T. S. (1981). Fine structure of the micropylar apparatus of the chum salmon egg, with discussion of the mechanism for blocking polyspermy. J. Exp. Zool. 217, 265-275.

Laale, H.W. (1980). The perivitelline space and egg envelopes of body fishes: a review. Copeia 2, 210-226.

Lagler, K.F. (1959). Freshwater Fishery Biology. 2nd edn. Dubuque: WM.C. Brown Company. 421 pp.

Linhart, O. \& Kudo, S. (1997). Surface ultrastructure of paddlefish egg before and after fertilization. J. Fish Biol. 51(3), 573-582.

Lopes, R.N.M., Senhorini, J. A. \& Soares, M.C.F. (1995). Desenvolvimento embrionário e larval do matrinxã Brycon cephalus Gunther, 1869, (PISCES, CHARACIDAE). Boletim Técnico CEPTA 8, 25-39.

Luz, R.K., Reynalte-Tataje, D.A., Ferreira, A.A. \& ZaniboniFihlo, E. (2001). Desenvolvimento Embrionário e Estágios Larvais do Mandi-Amarelo, Pimelodus maculatus. Boletim do Instituto de Pesca 27(1), 49-55.

Matrinxã (2005). Available from: http://www.geocities. com/sergiotoledomg/Peixes/ matrinxa.htm.

Morrison, C.M., Miyake, T. \& Wright, Jr. J. (2001). Histological study of the development of the embryo and early larva of Oreochromis niloticus (Pisces; Cichlidae). J. Morphol. 247, 172-195.

Nakaghi, L.S.O., Marques, C., Paes, M.C.F, Faustino, F, Ganeco, L.N. \& Senhorini, J.A. (2005). Análise do desenvolvimento embrionário do dourado (Salminus maxillosus) por meio de microscopia óptica. In Anais do 17 CONGRESSO DE INICIAÇÃO CIENTÍFICA, Jaboticabal.

Nelson, G. (1984). Peixes Amazônicos. Revista Brasileira de Zoologia 11, 29-45.

Ninhaus-Silveira, A. (2004). Desenvolvimento embrionário e preservação criogênica de embriões do curimbatá, Prochilodus lineatus (Valencinnes, 1836) (Teleostei; Prochilodontidae). Doctor's degree. Universidade Estadual Paulista-IBB, Botucatu.

Ninhaus-Silveira, A., Foresti, F., Azevedo, A., VeríssimoSilveira, R. \& Senhorini, J.A. (2006a). Semen characterization, cryogenic preservation and fertility in matrinxã, Brycon cephalus (Günther, 1860) (TELEOSTEI; CHARACIDAE). Braz. Arch. Biol. Tech. 49(4), 651-659.

Ninhaus-Silveira, A., Foresti, F., Azevedo, A. (2006b). Structural and ultrastructural analysis of embryonic development of Prochilodus lineatus (Valenciennes, 1836) (Characiforme, Prochilodontinae). Zygote 14, 217229.

Ohta, T. (1991). Initial stages of sperm-egg fusion in the freshwater teleost, Rhodeus ocellatus. The Anatomical Record 229(2), 195-202.

Pereira Filho, M. (1994). Estudo desenvolvidos no INPA (Manaus-Amozonas) com o matrinchã, Brycon cephalus (Günther, 1869). In Anais do Seminário Sobre Criação Do Gênero Brycon-Cepta, pp. 25-30, Pirassununga.

Ribeiro, C.R., Leme dos Santos, H.S. \& BOLZAN, A.A. (1995). Estudo comparativo da embriogênese de peixes ósseos (Pacu, Piaractus mesopotâmicus; Tambaqui, Colossoma macropomum e o híbrido Tambacu). Rev. Brás. Biol. 55(1), 65-78.

Riehl, R. (1980). Micropyle of some salmonids and coregonids. Env. Biol. Fishes. 5, 59-66.

Riehl, R. (1993). Surface Morphology and Micropyle as a Tool for Indentifying Fish Eggs by Scanning Electron Microscopy. Germany: University of Düsseldorf, pp. 29-31.

Rizzo, E. (2001). Biologia de ovos de peixes neotropicais de água doce: estudos comparativo e experimental, com ênfase na análise de superfície do aparelho micropilar. Doctor's degree. Universidade Federal de Minas Gerais, Belo Horizonte.

Rizzo, E., Sato, Y., Barreto, B.P. \& Godinho, H.P. (2002). Adhesiveness and surface patterns of eggs in neotropical freshwater teleosts. J. Fish Biol. 61, 615-632.

Rizzo, E. \& Bazzoli, N. (1993). Oogenesis, oocyte surface and micropylar apparatus of Prochilodus affinis Reinhardt, 1874 (Pisces Characiformes). Eur. Arch. Biol. 104, 1-6. 
Romagosa, E., Narahara, M. Y. \& Fenerich-Verani, N. (2001). Stages of embryonic development of the 'matrixã,' Brycon cephalus (Pisces, Characidae). Boletim do Instituto de Pesca 27(1), 27-32.

Shardo, J.D. (1995). Comparative Embryology of Teleostean Fishes. I. Development and Staging of the American Shad, Alosa sapidissima (Wilson, 1811). J. Morphol. 225, 125-167.
Silveira, A.N. (2000). Caracterização espermática, preservação criogênica e fertilidade do matrinxã, Brycon cephalus (Günther, 1860) (Teleostei, Characidae). Masters degree. Universidade estadual paulista - IBB, Botucatu.

Woynarovich, E. \& Hovárth, L. (1983). A propagação artificial de peixes de águas tropicais. 220p. Brasília: FAO/CODEVASFCNPq. 